\title{
The Effects of Red Blood Cells Parameters on HbA1c and Random Blood Sugar Levels in Diabetics Diagnosis
}

\author{
Esraa R Rashed ${ }^{1}$, Tasneem A Alkout ${ }^{2}$, Saja S Eltomy ${ }^{1}$, Osama R Etekbali ${ }^{1}$ and Abdulhamid M Alkout ${ }^{1,3^{*}}$ \\ ${ }^{1}$ Albarra Hospital, Ben Ashour Street, Tripoli, Libya \\ ${ }^{2}$ Faculty of Medicine, University of Tripoli, Tripoli, Libya \\ ${ }^{3}$ Medical Laboratory Department, Faculty of Medical Technology, University of Tripoli, Tripoli, Libya

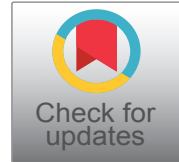

*Corresponding author: Prof. Abdulhamid M Alkout, Faculty of Medical Technology, University of Tripoli, Tripoli, P.O. Box 4483, Libya, Tel: 00218913753493

\begin{abstract}
Background: Hemoglobin A1c levels and blood sugar is a diagnostic tests used for diabetes and to determine the developing of diabetic complications. The level of $\mathrm{HbA} 1 \mathrm{c}$ is affected by factors such as the Haemoglobin, the age of $\mathrm{RBCs}$ in the blood circulation and the $\mathrm{Hb}$ glycation rate. The aim of this retrospective study is to assess the relationship of $\mathrm{HbA} 1 \mathrm{c}$ levels and blood sugar with haemoglobin concentration, and RBC parameter during female clinic follow-up.

Material and Method: The $\mathrm{HbA} 1 \mathrm{c}$ levels of 202 patients was measured by NycoCard reader II analyzer and RBC, Haemoglobin concentration $(\mathrm{Hb})$, hematocrit $(\mathrm{Hct})$, Mean Corpuscular Volume (MCV), Mean Corpuscular Haemoglobin $(\mathrm{MCH})$ and Mean Corpuscular Hemoglobin Concentration (MCHC) was measured by mindray $\mathrm{BC}-3000$ Plus auto haematology analyzer, the statistical analyses were performed with SPSS software version 16.0. The Spearman correlation coefficient was used for the relationship of $\mathrm{HbA} 1 \mathrm{c}$, blood sugar with RBC parameters and Kruskal Wallis test for the comparison of $\mathrm{HbA} 1 \mathrm{c}$ and $\mathrm{RBC}$ parameters between the Diabetics, pre-diabetic and non-diabetic patients.
\end{abstract}

Results: The correlation of $\mathrm{HbA} 1 \mathrm{c}$ and blood sugar levels with RBC parameter indicates positive correlation with RBC count and negative correlation with $\mathrm{MCV}$ and $\mathrm{MCH}$, and the comparison among diabetic, pre-diabetic and non-diabetic patients, the results showed significantly higher mean of $\mathrm{RBC}$ count, $\mathrm{Hb}$ concentration and Hct in diabetic patients, and the mean $\mathrm{MCV}$ and $\mathrm{MCH}$ were significantly higher in non-diabetic compared with pre-diabetic and diabetic.

Conclusion: The low level of $\mathrm{HbA} 1 \mathrm{c}$ has been found in shorten RBCs lifespan, which is affected by RBC parameters and decrease of RBC lifespan in hyperglycaemia patients. Therefore, this study concludes that the RBC parameters are an excellent tool parallel with $\mathrm{HbA} 1 \mathrm{c}$ and blood sugar for the assessment of diabetes patients.

\author{
Keywords \\ HbA1c, Blood sugar, RBC parameters
}

\section{Introduction}

Hemoglobin A1c (HbA1c) levels is one of the diagnostic tests used for diabetes and managing hyperglycemia in uncontrolled diabetic patients [1]. It is synthesis from the glycation of the terminal unit of the $\beta$-chain of haemoglobin, and there percentages determined by the plasma glucose level during last six to eight weeks [2], it has been used to evaluate the level of metabolic control and to determine the developing of diabetic complications, as well as measuring the quality of diabetes care [3].

Anaemia is one of the fundamental elements that effect theHbA1c values by increased the Red Blood Cells count (RBCs) leading to decrease HbA1c levels, which it has been found in blood loss, haemolysis, haemoglobinopathies, red cell disorders, myelodysplastic disease and in patient with haemolytic anaemia, these observations indicated that $\mathrm{HbA1C}$ is a very poor marker for diabetic patient with haemolytic anaemia [2,4-7]. While the decreased in RBCs count leading to an increase in the glycation rate of the $\mathrm{Hb}$ which contributes to the high value of $\mathrm{HbA1c}$ as shown in patients with splenectomy or iron deficiency anaemia [8].

Epidemiological and clinical studies suggested that iron deficiency anaemia causes an increase of $\mathrm{HbA1c}$ levels and reduced after iron therapy [9-12]. The level

Citation: Rashed ER, Alkout TA, Eltomy SS, Etekbali OR, Alkout AM (2020) The Effects of Red Blood Cells Parameters on HbA1c and Random Blood Sugar Levels in Diabetics Diagnosis. Int J Diabetes Clin Res 7:128. doi.org/10.23937/2377-3634/1410128

Accepted: September 28, 2020: Published: September 30, 2020

Copyright: (C) 2020 Rashed ER, et al. This is an open-access article distributed under the terms of the Creative Commons Attribution License, which permits unrestricted use, distribution, and reproduction in any medium, provided the original author and source are credited. 
of $\mathrm{HbA1C}$ is affected by factors such as the $\mathrm{Hb}$ content of reticulocytes, the mean age of RBCs in the blood circulation and the $\mathrm{Hb}$ glycation rate $[13,14]$. The aim of this retrospective study is to assess the relationship of $\mathrm{HbA} 1 \mathrm{c}$ levels and blood sugar with haemoglobin concentration, and RBC parameter during female clinic follow-up.

\section{Material and Method}

This retrospective study of 202 patients among them is 71 patients' non-diabetic, 88 patients pre-diabetic and 43 diabetic during female clinic follow-up at Albaraa hospital from February to December 2019. The HbA1C was measured by NycoCard reader II analyzer using the boronate affinity chromatography that calculates the ratio between glycated haemoglobin and total haemoglobin after lysing of RBC. RBC, Hb, Hct, MCV, $\mathrm{MCH}$ and $\mathrm{MCHC}$, was measured by mindray $\mathrm{BC}-3000$
Plus auto haematology analyzer for in vitro diagnostic use in clinical laboratories, and random blood glucose level was performed by Enzymatic Colorimetric (GODPAP) technique using biomaghreb kit measured 4040 photometer.

The statistical analyses were performed with SPSS software version 16.0. The Spearman correlation coefficient was used for the relationship of HbA1c, random blood sugar with RBC parameters and Kruskal Wallis test was used for the comparison of HbA1c and RBC parameters between the Diabetics, pre-diabetic and non-diabetic patients.

\section{Results}

Two hundred and two female with a mean age 36-years-old refereed to female's clinic, there were 71 non-diabetic, 88 pre-diabetic and 43 diabetic patients were included in this study, the correlation results

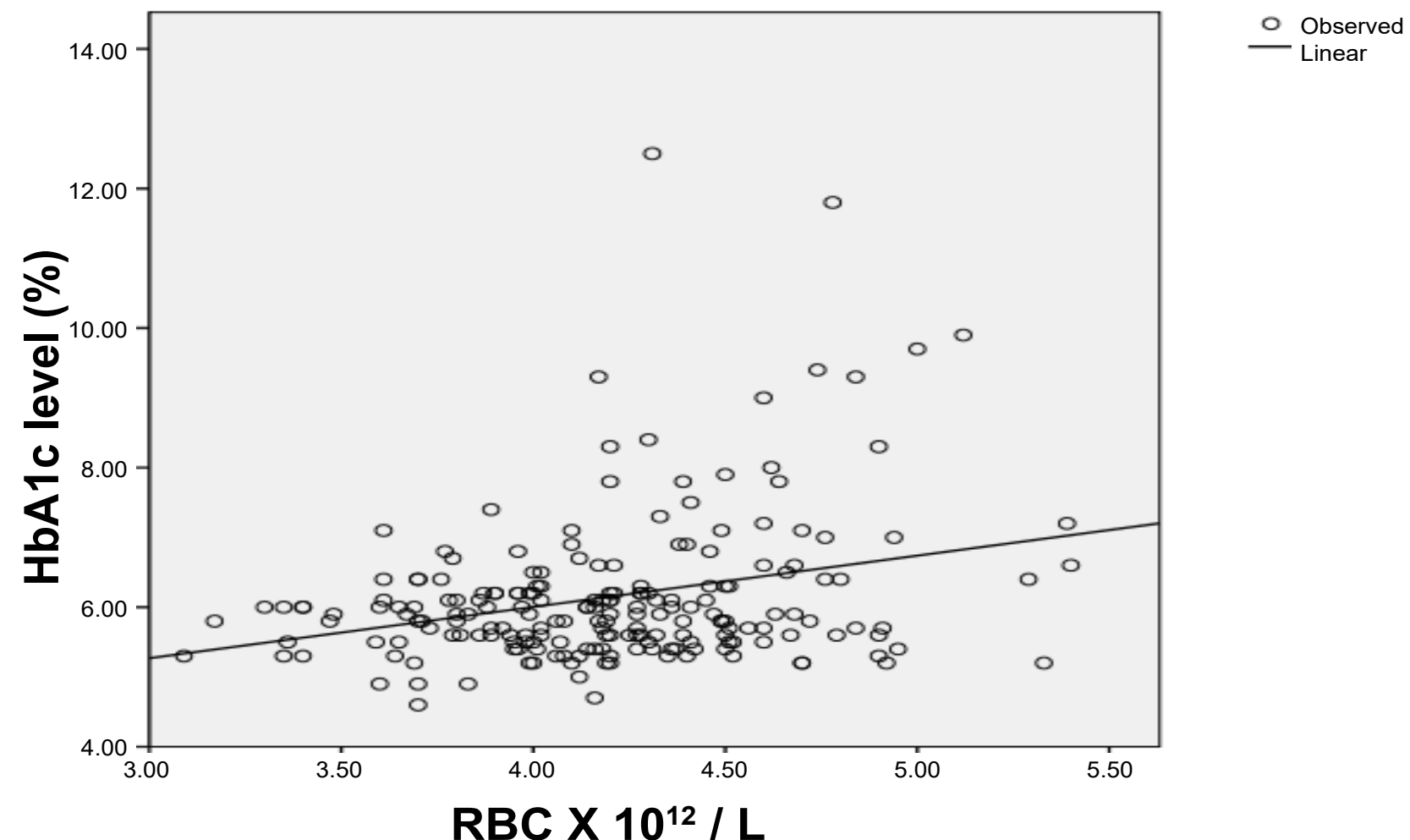

Figure 1: The correlation between the $\mathrm{HbA} 1 \mathrm{c}$ levels with RBC count.

Table 1: The summary of Spearman correlation coefficient between HbA1c, Blood sugar and RBC parameters 202 patients.

\begin{tabular}{|c|c|c|c|c|c|c|c|c|c|}
\hline \multicolumn{2}{|c|}{ Spearman's rho } & \multirow{2}{*}{\begin{tabular}{|l} 
HbA1c \\
1.000 \\
\end{tabular}} & \multirow{2}{*}{\begin{tabular}{|l} 
RBC \\
$0.189^{* *}$ \\
\end{tabular}} & \multirow{2}{*}{$\begin{array}{l}\mathbf{H b} \\
-0.005\end{array}$} & \multirow{2}{*}{$\begin{array}{l}\text { Hct } \\
0.001\end{array}$} & \multirow{2}{*}{$\begin{array}{l}\text { MCV } \\
-0.270^{* *}\end{array}$} & \multirow{2}{*}{\begin{tabular}{|l|} 
MCH \\
$-0.159^{*}$ \\
\end{tabular}} & \multirow{2}{*}{$\begin{array}{l}\text { MCHC } \\
-0.064\end{array}$} & \multirow{2}{*}{$\begin{array}{l}\text { Sugar } \\
0.461^{* *}\end{array}$} \\
\hline HbA1c & Correlation Coefficient & & & & & & & & \\
\hline & Sig. (2-tailed) & 0.000 & 0.007 & 0.941 & 0.987 & 0.000 & 0.024 & 0.363 & 0.000 \\
\hline & $N$ & 202 & 202 & 202 & 202 & 202 & 202 & 202 & 202 \\
\hline \multirow[t]{3}{*}{ Sugar } & Correlation Coefficient & $0.461^{* *}$ & $0.255^{* *}$ & 0.133 & 0.108 & $-0.230^{* *}$ & $-0.171^{*}$ & -0.100 & 1.000 \\
\hline & Sig. (2-tailed) & 0.000 & 0.000 & 0.060 & 0.125 & 0.001 & 0.015 & 0.158 & 0.000 \\
\hline & $\mathrm{N}$ & 202 & 202 & 202 & 202 & 202 & 202 & 202 & 202 \\
\hline
\end{tabular}


of $\mathrm{HbA1C}$, random blood sugar with $\mathrm{RBC}$ parameter indicated there was significant positive correlation of HbA1c with RBC count $(p<0.007)$ (Figure 1$)$, and insignificant positive correlation with $\mathrm{Hct}(\mathrm{p}<0.987)$, while there were significant negative correlation with MCV $(p<0.000)$ (Figure 2), MCH $(p<0.024)$ (Figure 3$)$, but there were insignificant negative correlation with $\mathrm{Hb}$ concentration and $\mathrm{MCHC}$ (Table 1 ).

The correlation of blood sugar with RBC parameter showed significantly positive correlation with RBC count $(p<0.000)$ (Figure 4$)$ and significant with $\mathrm{Hb}$ concentration ( $p<0.060$ ) (Figure 5$)$, while it was significant negative correlation with MCV $(p<0.001)$ (Figure 6), MCH $(p<0.015)$ (Figure 7$)$, and it was an insignificant correlation with Hct and insignificant negative correlation with $\mathrm{MCHC}$ (Table 1).

Table 2 summarizes the comparison of the RBC parameters mean values among diabetic, pre-diabetic and non-diabetic patients, the results showed that the mean RBC count in diabetic patients were significantly higher $\left(4.4 \times 10^{12} / \mathrm{L}\right)$ than in non-diabetic $\left(4.2 \times 10^{12} / \mathrm{L}\right)$ and pre-diabetic $\left(4.1 \times 10^{12} / L\right)(p<0.000)$, the Hct values

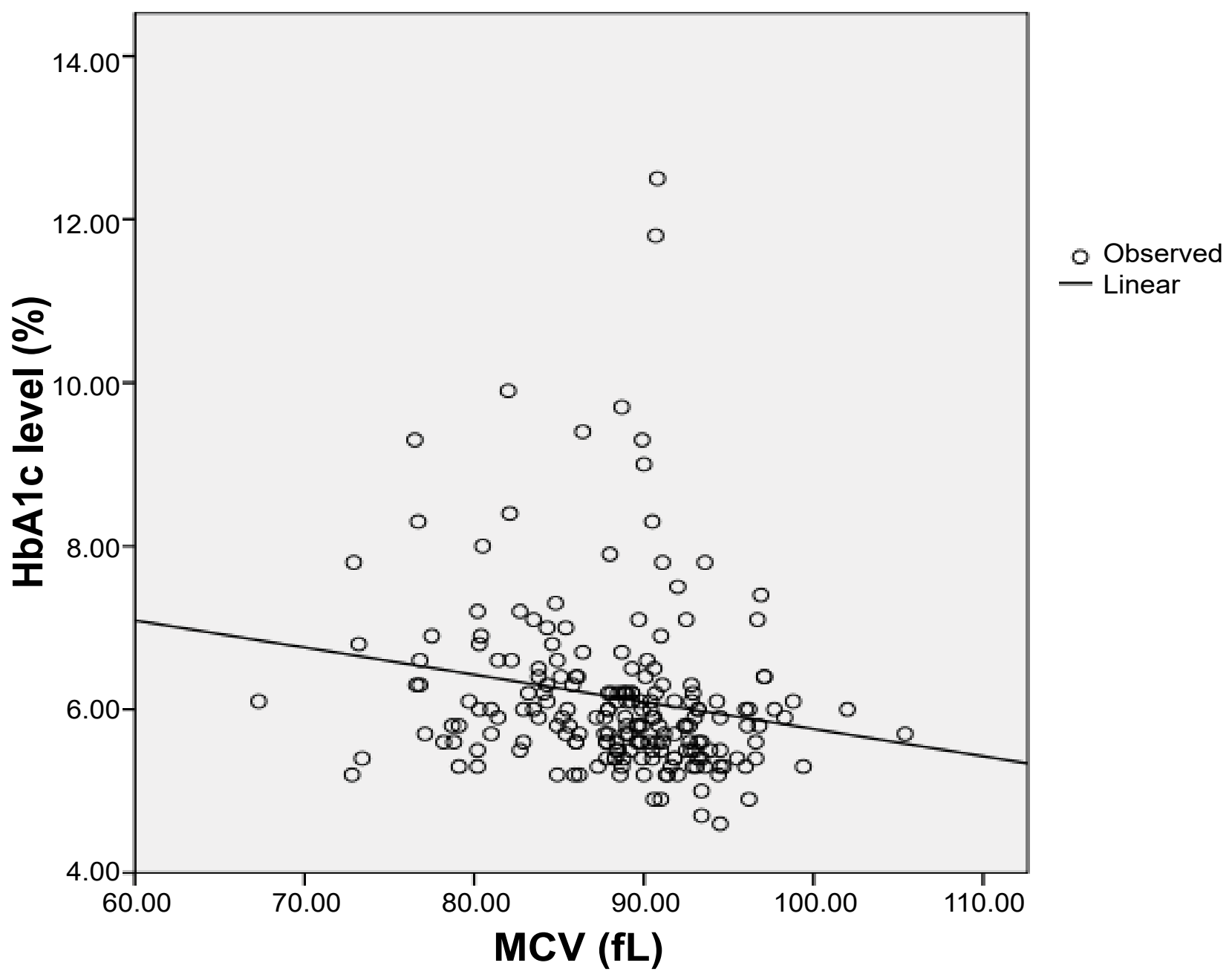

Figure 2: The correlation between the $\mathrm{HbA1c}$ levels with $\mathrm{MCV}$.

Table 2: The comparison of the mean RBC parameters among Non Diabetic, Pre-Diabetic and Diabetic patients.

\begin{tabular}{|c|c|c|c|c|c|c|c|c|c|c|}
\hline Stats & No & Range & $\begin{array}{l}\text { Mean } \\
\text { HbA1c\% }\end{array}$ & $\begin{array}{l}\text { Mean } \\
\text { sugar } \\
\text { mg/dl }\end{array}$ & $\begin{array}{l}\text { Mean } \\
\text { RBC } \\
X 10^{12} / \mathrm{L}\end{array}$ & $\begin{array}{l}\text { Mean Hb } \\
\text { g/dl }\end{array}$ & $\begin{array}{l}\text { Mean } \\
\text { HCT } \\
\%\end{array}$ & $\begin{array}{l}\text { Mean } \\
\text { MCV } \\
\text { fL }\end{array}$ & $\begin{array}{l}\text { Mean } \\
\text { MCH } \\
\text { pg }\end{array}$ & $\begin{array}{l}\text { Mean } \\
\text { MCHC } \\
\text { g/dl }\end{array}$ \\
\hline $\begin{array}{l}\text { Non } \\
\text { Diabetic }\end{array}$ & 71 & $4-5.6$ & 5.37 & 77 & 4.2 & 11.1 & 37.3 & 89.7 & 26.5 & 29.6 \\
\hline Pre-Diabetic & 88 & $5.7-6.4$ & 6.01 & 81 & 4.1 & 10.7 & 36.2 & 88.6 & 26.3 & 29.4 \\
\hline Diabetic & 43 & $>6.5$ & 7.7 & 140 & 4.4 & 11.3 & 38.1 & 85.6 & 25.4 & 29.6 \\
\hline \multirow{2}{*}{\multicolumn{3}{|c|}{$X^{2}$}} & & 49.83 & 18.97 & 10.30 & 10.11 & 14.55 & 7.12 & 1.36 \\
\hline & & & & 2 & 2 & 2 & 2 & 2 & 2 & 2 \\
\hline \multicolumn{3}{|l|}{$\mathrm{P}$ value } & & 0.000 & 0.000 & 0.006 & 0.006 & 0.001 & 0.028 & 0.507 \\
\hline
\end{tabular}




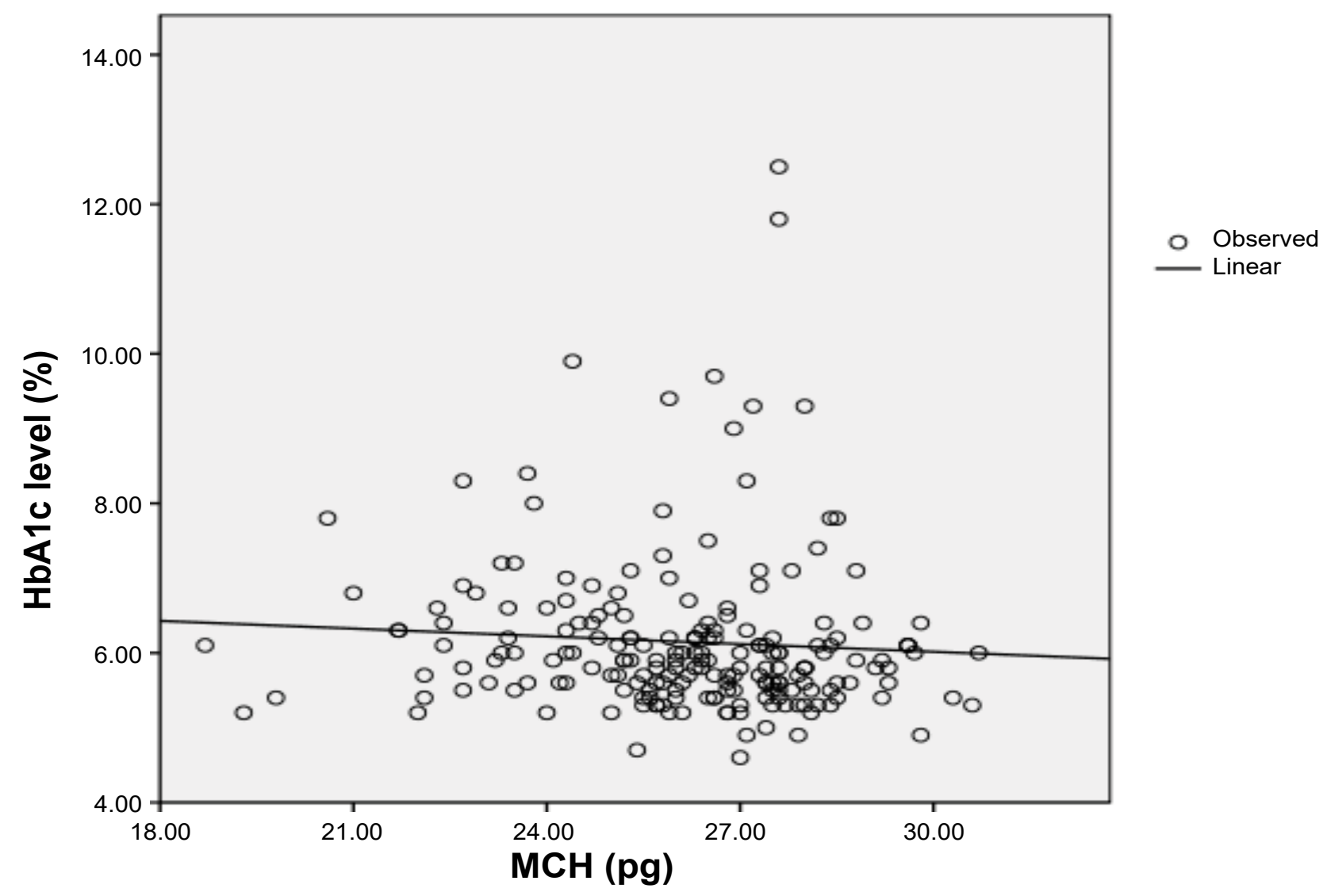

Figure 3: The correlation between the $\mathrm{HbA} 1 \mathrm{c}$ levels with $\mathrm{MCH}$.

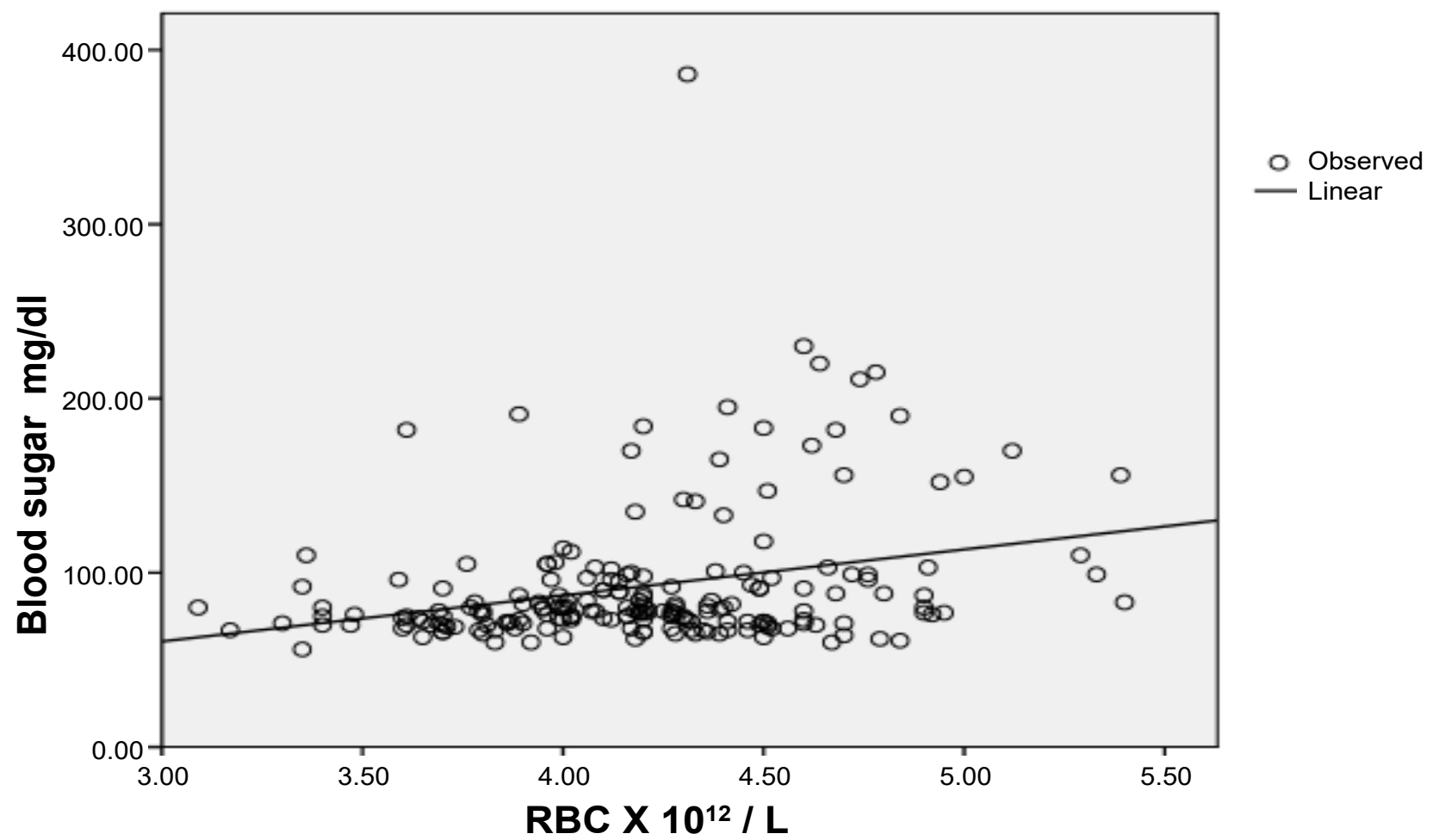

Figure 4: The correlation between the blood sugar levels with RBC count.

and the mean $\mathrm{Hb}$ concentration were significantly higher in diabetic cases ( $\mathrm{Hct}=38.1 \%, \mathrm{Hb}=11.3 \mathrm{~g} / \mathrm{dl}$ ) followed by non-diabetic $(\mathrm{Hct}=37.1 \%), \mathrm{Hb}=11 \mathrm{~g} / \mathrm{dl})$ and prediabetic ( $\mathrm{Hct}=35.7 \%, \mathrm{Hb}=10.6 \mathrm{~g} / \mathrm{dl}),(\mathrm{p}<0.006 ; \mathrm{Hb} ; \mathrm{p}$ $<0.006$ ), while the mean MCV and the mean $\mathrm{MCH}$ were significantly higher in non-diabetic (MCV $=89.4 \mathrm{fL}, \mathrm{MCH}$ $=26.4 \mathrm{pg})$ compared with pre-diabetic $(\mathrm{MCV}=88.4 \mathrm{fL}$, $\mathrm{MCH}=26.2 \mathrm{pg}$ ) and diabetic $(\mathrm{MCV}=85.6 \mathrm{fL}, \mathrm{MCH}=25.4$ pg) (MCV; $p<0.001, \mathrm{MCH} ; \mathrm{p}<0.028$ ) and there were no significant result with $\mathrm{MCHC}$ were observed (Table 2). 


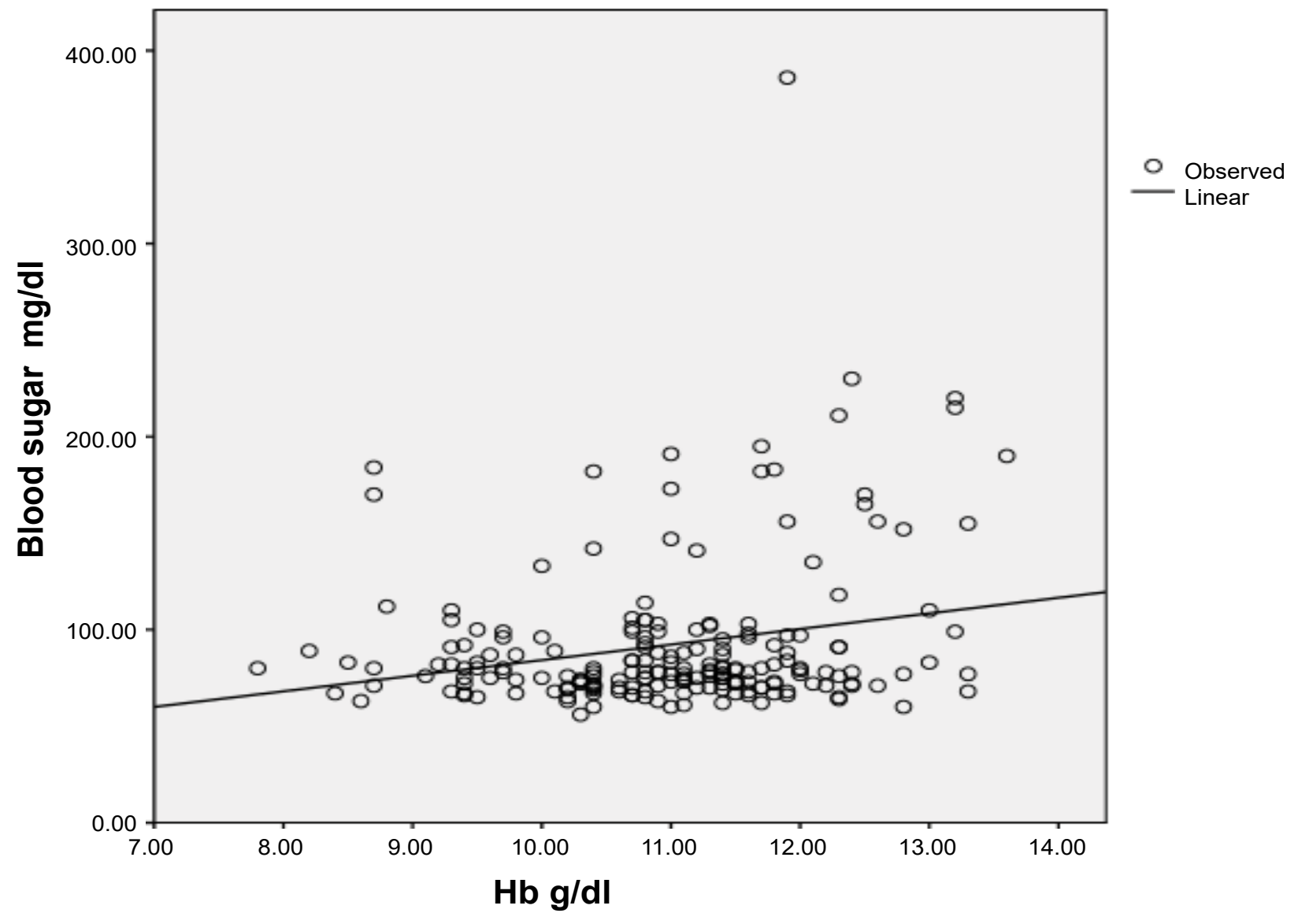

Figure 5: The correlation between the blood sugar levels with $\mathrm{Hb}$ concentration.

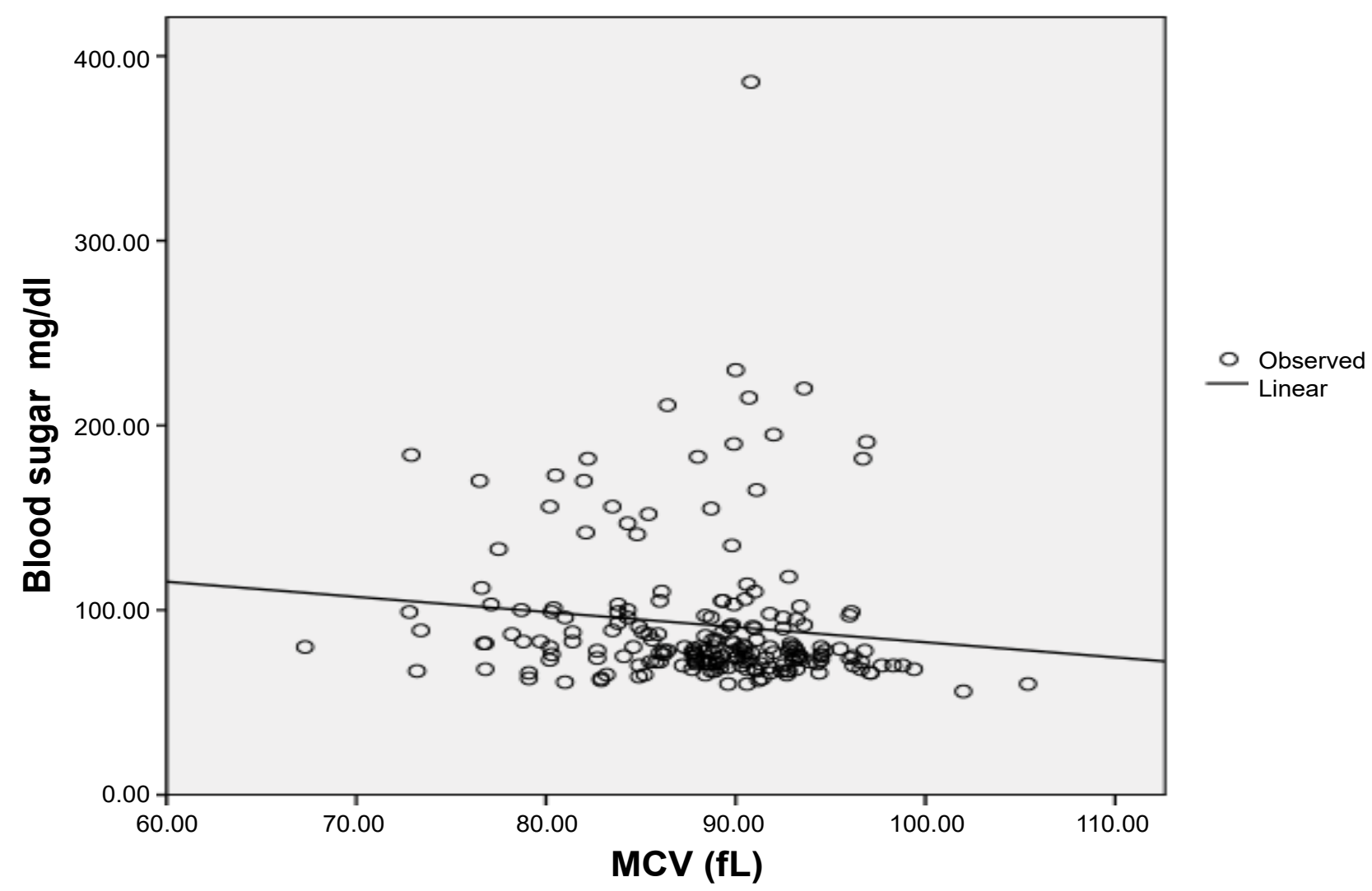

Figure 6: The correlation between blood sugar levels with MCV. 


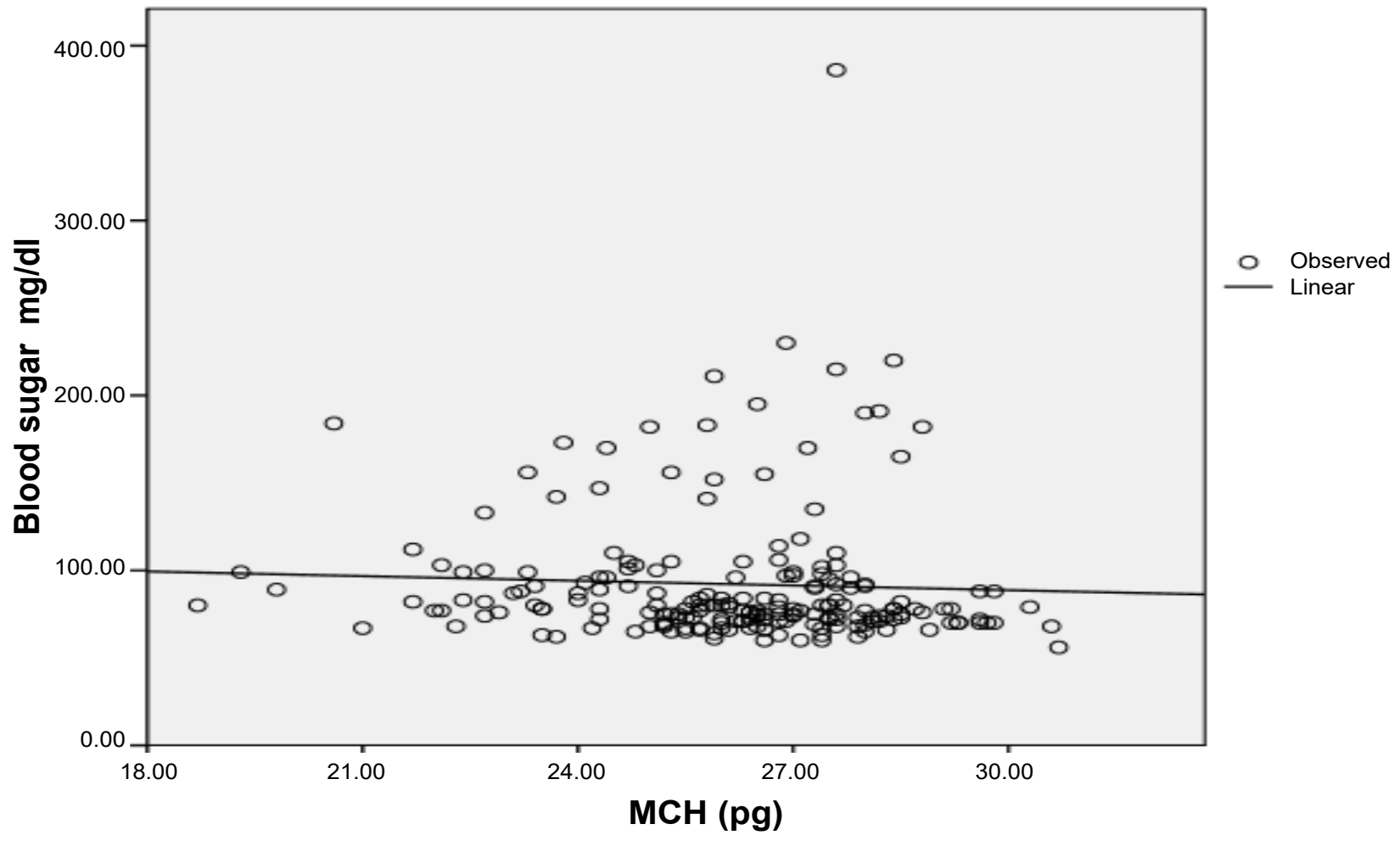

Figure 7: The correlation between the blood sugar levels with $\mathrm{MCH}$.

\section{Discussion}

HbA1c level has an important role for clinical diagnosis of diabetes [15] and it has been affected by anaemia in both ways positively and negatively according to the type of anaemia, such as blood loss, and haemolytic anaemia may increase RBC turnover and decrease $\mathrm{HbA1c}$ level, while iron deficiency anaemia and decrease in ferritin level contributes to an increase in RBC lifespan leading to an increase of $\mathrm{HbA} 1 \mathrm{c},[4,10]$, therefore RBC lifespan is one of the factors affecting $\mathrm{HbA1c}$ level production [16]. Our study showed a significant negative correlation of $\mathrm{HbA1C}$ with $\mathrm{MCV}$ and $\mathrm{MCH}$ and a significant positive correlation with RBC count, these observation supports the previous studies of inverse correlation between $\mathrm{MCH}$ and $\mathrm{HbA1c}$ in pregnant women [17], negative correlation of $\mathrm{HbA} 1 \mathrm{c}$ with $\mathrm{Hb}, \mathrm{MCV}$ and $\mathrm{MCH}$ in diabetic patients and premenopausal women [18-20] and positive correlation with RBC count in premenopausal women [19]. While our study is differ from the study of adult with no history of diabetes, which showed a significantly positive association between $\mathrm{MCH}, \mathrm{MCHC}$, RDW with $\mathrm{HbA1c}$ [21] and positive correlation with $\mathrm{Hct}$, $\mathrm{Hb}$ and $\mathrm{MCHC}$ values in non-diabetic pregnant women [13].

RBC lifespan decreased in hyperglycaemia patients [22] and affected negatively by $\mathrm{MCV}, \mathrm{MCH}$ and positively by $\mathrm{MCHC}$ [23], therefore this study designed to assess the correlation of blood sugar with RBC parameter and the results showed a positive correlation of blood sugar with $\mathrm{Hb}$ concentration and RBC count, while there was a negative correlation with MCV and
$\mathrm{MCH}$, this observation supports the relationship of RBC parameters with blood sugars levels.

Two hundred and two patients divided into three groups according to their $\mathrm{HbA1c}$ level non-diabetic (4-5.6), pre-diabetic (5.7-6.4) and diabetic ( $\geq 6.5$ ) has been classified by American Diabetes Association [24]. Our result showed non-diabetic group has significantly higher mean MCV and $\mathrm{MCH}$ than pre-diabetic and diabetic groups, while diabetic group has significantly higher mean RBC, $\mathrm{Hb}$ concentration and Hct than nondiabetic and pre-diabetic groups, these results disagree with the previous study which indicate that RBC count increased in pre-diabetic patient and decreased in patient with diabetes mellitus [25].

\section{Conclusion}

$\mathrm{HbA1c}$ and blood sugar levels is an excellent tool for diabetes diagnosis, it has been shown that RBC lifespan decreased in hyperglycaemia patients [22], and the low level of $\mathrm{HbA1c}$ has been found in shorten RBCs lifespan [26], also MCV and $\mathrm{MCH}$ are factors affecting RBC lifespan [20,23]. Our results indicate that MCV and $\mathrm{MCH}$ values increased in patients with lower levels of $\mathrm{HbA} 1 \mathrm{c}$ and non-diabetic patients, while RBC count increased in patients with higher levels of $\mathrm{HbA1C}$, and diabetic patients have the highest mean RBC count and $\mathrm{Hb}$ concentration while non-diabetic patients have significantly higher mean $\mathrm{MCV}$ and $\mathrm{MCH}$. This study provide clear understanding of the multiple factors that determine $\mathrm{HbA1c}$ in whole blood and we conclude that the using of $\mathrm{HbA1C}$ and blood sugar only as a diagnostic tool may gives false patient assessments, therefore 
$\mathrm{RBC}$ count, $\mathrm{MCV}, \mathrm{MCH}$, and $\mathrm{Hb}$ concentration is needed to be bounded with $\mathrm{HbA} 1 \mathrm{c}$ level and to identify the anaemia type for more accurate diabetic assessments. Correlations study of RBC parameters and anaemia type with other diabetic laboratory investigations and other glycemic control investigation such as oral glucose tolerance test is needed to assess the importance of this observation and provide a more complete understanding of diabetic patients.

\section{Acknowledgment}

This work is supported by Albaraa Hospital Laboratory department and the group would like to express their deep appreciation and indebtedness particular to Dr. Alhadi Araibi and Mr. Abdullah Kredan for their support and understanding the useful of this study.

\section{References}

1. World Health Organization (2011) Use of Glycated Haemoglobin $(\mathrm{HbA} 1 \mathrm{c})$ in the Diagnosis of Diabetes Mellitus. Abbreviated Report of a WHO Consultation.

2. Segun Adeoye, Sherly Abraham, Irina Erlikh, Sylvester Sarfraz, Tomas Borda, et al. (2014) Anemia and hemoglobin A1c level: Is there a case for redefining reference ranges and therapeutic goals? British Journal of Medical Practitioners 7: a706.

3. Nadia Hussain (2015) Haemoglobin A1c and iron deficiency anaemia our understanding through the decades. Rom J Diabetes Nutr Metab Dis 22: 289-296.

4. Robert S Franco (2008) The measurement and importance of red cell survival. Am J Hematol 84: 109-114.

5. Nidhi Aggarwal, Anand Kumar Rai, Yizhak Kupfer, Sidney Tessler (2013) Immeasurable glycosylated haemoglobin: A marker for severe haemolysis. BMJ Case Rep 2013: bcr2013200307.

6. Koga M, Hashimoto K, Murai J, Saito H, Mukai M, et al. (2011) Usefulness of glycated albumin as an indicator of glycemic control status in patients with hemolytic anemia. Clin Chim Acta 412: 253-257.

7. Earl S Ford, Catherine C Cowie, Chaoyang Li, Yehuda Handelsman, Zachary T Bloomgarden (2011) Iron-deficiency anemia, non-iron-deficiency anemia and $\mathrm{HbA} 1 \mathrm{c}$ among adults in the US. J Diabetes 3: 67-73.

8. Zhenhe Huang, Yajing Liu, Yanfang Mao, Wenwen Chen, Zhangang Xiao, et al. (2018) Relationship between glycatedhaemoglobin concentration and erythrocyte survival in type 2 diabetes mellitus determined by a modified carbon monoxide breath test. J Breath Res 12: 026004.

9. Jen M Ng, Michelle Cooke, Sunil Bhandari, Stephen L Atkin, Eric S Kilpatrick (2010) The effect of iron and erythropoietin treatment on the $\mathrm{A} 1 \mathrm{C}$ of patients with diabetes and chronic kidney disease. Diabetes Care 33: 2310-2313.

10. Alap L Christy, Poornima A Manjrekar, Ruby P Babu, Anupama Hegde, Rukmini MS (2014) Influence of iron deficiency anemia on hemoglobin A1C levels in diabetic individuals with controlled plasma glucose levels. Iran Biomed J 18: 88-93.

11. Catherine Kim, Kai McKeever Bullard, William H Herman, Gloria L Beckles (2010) Association between iron deficiency and $\mathrm{A} 1 \mathrm{C}$ levels among adults without diabetes in the $\mathrm{Na}$ tional Health and Nutrition Examination Survey, 1999-2006. Diabetes Care 33: 780-785.
12. Ashraf T Soliman, Vincenzo De Sanctis, Mohamed Yassin, Nada Soliman (2017) Iron deficiency anemia and glucose metabolism. Acta Biomed 88: 112-118.

13. Awad-ElkareemAbass, Imad R Musa, Duria A Rayis, Ishag Adam, Gasim I Gasim (2017) Glycatedhemoglobin and red blood cell indices in non-diabetic pregnant women. Clin Pract 7: 999.

14. Jeffcoate SL (2003) Diabetes control and complications: The role of glycated haemoglobin, 25 years on. Diabetic Medicine 21: 657-665.

15. Tennyson $\mathrm{C}$, Lee $\mathrm{R}$, Attia $\mathrm{R}$ (2013) Is there a role for $\mathrm{HbA1c}$ in predicting mortality and morbidity outcomes after coronary artery bypass graft surgery? Interact Cardiovasc Thorac Surg 17: 1000-1008.

16. Church D, Simmons D (2014) More evidence of the problems of using $\mathrm{HbA} 1 \mathrm{c}$ for diagnosing diabetes? The known knowns, the known unknowns and the unknown unknowns. J Intern Med 276: 171-173.

17. Tatsumi Moriya, Madoka Matsubara, Masafumi Koga (2014) Hemoglobin A1C but not glycated albumin overestimates glycemic control due to iron deficiency in pregnant women with diabetes. J Diabetes Metab 5: 445.

18. Farah J, Husan AR, Farha AAZW (2013) Hyperglycemic induced variations in hematological indices in type 2 diabetics. International Journal of Advanced Research 8: 322-334.

19. M Koga, S Morita, H Saito, M Mukai, S Kasayama (2007) Association of erythrocyte indices with glycated haemoglobin in premenopausal women. Diabet Med 24: 843-847.

20. Pallavi S Hardikar, Suyog M Joshi, Dattatray S Bhat, Deepa A Raut, Prachi A Katre, et al. (2012) Spuriously high prevalence of prediabetes diagnosed by $\mathrm{HbA} 1 \mathrm{c}$ in young Indians partly explained by haematological factors and iron deficiency anemia. Diabetes Care 35: 797-802.

21. Jaman MS, Rahman MS, Swarna RR, Mahato J, Miah MM, et al. (2018) Diabetes and red blood cell parameters. Ann Clin Endocrinol Metabol 2: 001-009.

22. Virtue Mark A, Furne Julie K, Nuttall Frank Q, Levitt Michael D (2004) Relationship between $\mathrm{GHb}$ concentration and erythrocyte survival determined from breath carbon monoxide concentration. Diabetes Care 27: 931-935.

23. Bosch FH, Werre JM, Roerdinkholder-Stoelwinder B, Huls TH, Willekens FL, et al. (1992) Characteristics of red blood cell populations fractionated with a combination of counterflow centrifugation and Percoll separation. Blood 79: 254260.

24. American Diabetes Association (2019) Classification and diagnosis of diabetes: Standards of medical care in diabetes-2019. Diabetes Care 42: S13-S28.

25. Simmons D (2010) Increased red cell count in diabetes and pre-diabetes. Diabetes Res Clin Pract 90: e50-e53.

26. Robert M Cohen, Robert S Franco, Paramjit K Khera, Eric P Smith, Christopher J Lindsell, et al. (2008) Red cell life span heterogeneity in hematologically normal people is sufficient to alter HbA1c. Blood 112: 4284-4291. 